\author{
Ahmet ŞİT, Kilis ${ }^{1}$ \\ Burak BÜYÜKOĞLU² \\ İbrahim Halil EKŞ் ${ }^{3}$
}

\title{
IMPACT OF CORPORATE GOVERNANCE ATTRIBUTES ON AUDIT REPORT LAG OF CORPORATE: THE CASE OF BIST-30
}

\begin{abstract}
The purpose of this study is to investigate the effects of corporate governance behaviors on audit report lag. The lag of audit reports concerns investors and other parties. Therefore, it can affect the firm value of the enterprises. For this aim, 30 companies operating in Istanbul Stock Exchange (BIST) were used in this study. The data of the firms are taken from the independent audit reports. As the audit report lag, the difference between December 31 and of the date when companies announced their report was taken. In this study, we used the proportion of non-executive directors to total number of board, total assets, share of the largest shareholder and free float rate as corporate governance attributes. Findings of this study was based on the used system dynamic panel method. As a result, it was concluded that the corporate governance behaviors of the firms were not effective on the audit report lags of the firms.
\end{abstract}

Key words: Audit Reports Lag, Corporate Governance, System Dynamic Panel Jel: $G 32, G 34, M 21$

\section{INTRODUCTION}

Financial statements of firms are aimed at providing quality financial information for evaluation of firms' performance. The statements facilitate informed decision making as the content is of great value to users of statements. The information in corporate annual reports may be used to influence shareholders' impression of a firms' performance. Financial statements are vital to investors and other users, since they serve as a basis for financial decisions.

1 Assistant professor, Aralik University, Kilis/TURKEY. E-mail: ahmet.sit@hotmail.com

2 Lect. Gaziantep University, TURKEY. E-mail: bbuyukoglu@gantep.edu.tr

3 Associate professor, Gaziantep University, TURKEY. E-mail: eksihali1@gmail.com 
The one of the most important dimensions of financial statements is timeliness of financial information.

Timeliness is an auxiliary aspect of relevance. Timeliness means having information available to decision-makers, before it loses its influence capacity. If information is either unavailable when it is needed, or reaches its user too late that it has no value for future action, it lacks relevance and is of little or no use. Timeliness alone cannot make information relevant, but a lack of timeliness can rob information of relevance it might otherwise have had. (Mensah, 2018).

Against this backdrop, studies on the timeliness of accounting information have become very important, especially in technology based modern business world. Timely reporting in emerging capital markets is of particular importance since information in these markets is relatively limited and has a longer time lag. It will enhance decision making and reduce information asymmetry in the markets. Furthermore, examination of the determinants of timely reporting is crucial to regulators of the capital market who are involved in formulating policies that will enhance market efficiency (Ohaka and Akani, 2017).

One of the most effective factors on timeliness of financial reporting is corporate governance. Corporate governance is viewed as a system that delineates the rights and responsibilities of each major group of stakeholders in a company and spells out rules and procedures for making decisions about corporate affairs (Needless et al., 2012). A good corporate governance system facilitates the solution of interest conflicts between majority and minority shareholders, managers and shareholders, and also shareholders and stakeholders (Akdoğan and Boyacıŏlu, 2014). Corporate governance has become a frequently debated subject because the failures or abuses observed in the management of companies play a precipitating or deepening role in the financial crisis.

In relation to financial reporting timeliness, corporate governance may reduce the audit business risk of the company. Corporate governance, a system by which firms are directed and controlled in order to ensure their continuity in business, is the responsibility of senior management and the board of directors (Shukeri and Islam, 2012).

In this study, agency theory is considered as a relevant theory which is applicable to our paper. Because agency theory explains the board of directors, directors' ownership and audit committee, whereby each of them is functioning as a monitor of mechanism to reduce agency problems. Monitoring mechanism refers to the corporate governance practices, the proper management performance and financial reporting processes (Apadore and Noor, 2013). 
In this study, we investigate the effect of corporate governance on timeliness of financial reporting. For this aim, the data are obtained from the audit reports of 30 firms from the BIST 30 index. In this study, audit reporting lag is a dependent variable; whereas proportion of non-executive directors to total number of board, total assets, share of the largest shareholder and free float rate are independent variables. The study period was 5 years between 2013 and 2017. A method for this study that was used is system dynamic panel.

Turkey is an interesting country to study, for two reasons. First, Turkey has got an important middle-income developing market. Historically, Turkish legal rules and institutions have been weak and have given firms great flexibility to choose their governance practices (Ararat et al., 2012). Secondly, only a few researches about the effect of corporate governance on timeliness of financial reporting were conducted in Turkey. More precisely, there are only two papers (Özkan et al., 2013; Cengiz ve Tosunoğlu, 2017) close to this paper. This study is different in terms of both sample and used corporate governance variables.

\section{Literature}

There are a lot of dimensions of audit reporting timeliness. So, numerous researches were done on the topic timeliness. Some studies have investigated the timeliness of financial reporting and its determinants; some have examined financial reporting timeliness, audit committee characteristics timeliness, relevance of financial reporting; while others have researched the effect of financial reporting timeliness on firm performance. We observed that the most studies with timeliness of financial reporting are in relation to emerging countries like Ghana, Jordan, and Nigeria. In our opinion corporate governance degree is low in these countries. As a result, we investigated the effect of corporate governance on timeliness of financial reporting for Turkey as emerging country.

Prior papers suggest that the presence of corporate governance mechanisms will increase the monitoring of management and reduce the incidence of management or misreporting, or financial reporting lag (Shukeri and Islam, 2012; Naimi et al., 2010). With a hope of finding a parallel result with literature, this research was made.

Alkhatib and Marji (2012) aimed at reporting the results of an empirical investigation of factors that affect the timeliness of audit report in Jordan. The study sample includes 137 firms listed on the Jordanian Stock Exchange. The findings show that for the services sector profitability ratio, type of audit firm, and company size were negatively correlated with audit timeliness, where leverage was the only variable that has a significant correlation. 
Shukeri and Islam (2012) investigated the determinants of audit report timeliness particularly the effect of audit committee functions in Malaysian audit market for 2011. Their results show that audit report lag is influenced by audit committee size, audit committee meetings, auditor type, audit opinion, total assets and firm profitability. However, no evidence was found to support the effects of board independence and audit committee qualifications on audit report timeliness.

Yadirichukwu and Ebimobowei (2013) examined the effect of audit committee on timeliness of financial reports for thirty five firms quoted in the Nigerian Stock Exchange for the period 2007-2011. The result suggests that audit committee independence and audit committee expertise are significantly related to the timeliness of financial reports; while audit committee meeting and audit committee size are not significantly related to timeliness of financial reports.

Apadore and Noor (2013) analyzed the relation between the characteristics of corporate governance (board independence, ownership concentration, etc.) and audit report lag among companies listed under Bursa Malaysia for 2009 and 2010. According to regression analysis results, audit committee size, ownership concentration, organization size and profitability are significantly associated with audit report lag. However, the other six variables (audit committee independence, meetings, and expertise and auditor types) were found to have insignificant relationship with audit report lag.

Özkan et al. (2013) examined the relationship between the firm specific factors, financial statements and the independent audit reports which are the inseparable parts of those statements on Istanbul Stock Exchange for 2005-2010 period. Overall results show that non-financial firms reporting loss release their financial statements later than others.

Puasa et al. (2014) investigated the relationship between audit committee characteristics and timeliness of financial reporting and examined the changes on the timeliness of financial reporting after the revision of Malaysian Code on Corporate Governance in 2007 as compared to the period before revised code.

The objective of study of Azubike and Aggreh (2014) is to examine the determinants of audit report timeliness in Nigeria. Specifically, the study examines the effect of company size, profitability, complexity and audit firm type on audit report timeliness for 2010-2012. The Ordinary Least Squares (OLS) regression technique was utilized as the method of data analysis. The finding of the study shows the following; a significant relationship exists between board size and board independence and audit report lag; whereas significant relationship wasn't found between audit firm type and Audit report lag. 
Ilaboya and Christian (2014)'s study investigated corporate governance in relation to Audit report lag in Nigeria for 2007-2011. It specifically examined the effect of board size, board independence, audit firm type, audit committee size, audit committee independence and firm size on audit report lag. Data were analyzed using descriptive statistics correlation and Ordinary Least Square, (OLS) regression. They found that board size, audit firm type, and firm size had a significant effect while board independence and audit committee size had no significant effect on audit report lag.

Cengiz (2015) determined the effect of factors and levels of importance that affect the duration of financial reporting on the stock exchange Istanbul for 2011-2015. He tested eight hypotheses (size of audit firm, audit opinion, company size, company profitability, company age, financial leverage ratio, audit committee meeting frequency, and number of board members of the company) using panel data analysis. Findings show that the duration of publication of financial reporting, type of audit firm and audit opinion are statistically significant and there is a negative relationship between companies reporting profit in the current period and operating in the financial sector as well as leverage ratio.

This study differs from similar studies with regard to both sample and methodology making it a contribution to literature.

\section{Methodology}

The broad objective of the study was to examine the relationship between corporate governance and audit reporting lag in Turkey. As in previous studies, the audit reporting lag (ARL) was used as the dependent variable. Corporate governance characteristics and control variables are modeled as independent variables.

The study sample consists of the 30 companies listed on the Istanbul Stock Exchange (BIST). There are a lot of indexes on BIST. This paper investigated BİST 30 indexes, choosing the biggest 30 companies of stock market. We investigated for period of 2012-2017. Data were obtained from independent audit firms. The data analysis techniques include pooled regression approach, adopted in testing whether independent variables affect dependent variable or not (ARL).

The audit reporting lag model used in this study are adapted from prior studies (Mohamad-Nor et.al. 2010; Apadore and Noor, 2013). Model as follows:

$$
A R L_{i t}=\alpha_{0}+A R L_{i t-1}+\alpha_{1} P N E D_{i t}+\alpha_{2} I N S T O_{i t}+\alpha_{3} F M S_{i t}+\alpha_{4} S L S_{i t}+\varepsilon_{i t}
$$

In this study, dynamic panel data (Generalized Method of Movements-GMM) was used. There are several reasons for using GMM. The main reason of using dynamic panel is that the lagged values of the dependent variables of the model are also found 
among the explanatory variables of the model. The predictions made with the fixed and random effects models and the estimators reached are inconsistent. As the lagged dependent variable is correlated with the error term in case of the use of lagged dependent variables in the fixed effect and random effect models. In the literature, this situation has also been observed in the studies on this subject (Coşkun and Kök, 2011; Béjaoui and Bouzgarrou, 2014; Mnasri, 2015) Secondly, the financial data used in the model can show highly dynamic effects depending on the current time period (Tunay, 2014). Also, the length of time (T: from 2012 to 2017 as yearly) used in the data set is shorter than the bank size (N: 30 firms). This is a convenient situation for using GMM (Akbulut and Güran, 2015).

We adopted a dynamic specification of the model by including a lagged dependent variable among the regressors. When we select control variables, we depended on literature Ben Kwame Agyei-Mensah 2017, Puasa, Salleh and Ahmad 2014, Alkhatib and Marji 2012, Ferrero, 2014; Azubike and Aggeh, 2014, and Mohamad-Nor, Shafie and Wan-Hussin, 2010. As shown above, the relationship between ARL and corporate governance variables are tested.

Table 1: Dependent and Independent Variables

\begin{tabular}{|l|l|l|}
\hline \multicolumn{3}{|c|}{ DEPENDENT VARIABLES } \\
\hline Symbol & Variable & Definition \\
\hline ARL & Audit Reporting Lag & $\begin{array}{l}\text { Number of days that elapse between the company's } \\
\text { year-end and the date of the auditor's report }\end{array}$ \\
\hline \multicolumn{3}{|c|}{ INDEPENDENT VARIABLES } \\
\hline Symbol & Variable & Definition \\
\hline PNED & Board Independence & $\begin{array}{l}\text { The Ratio Of Non-Executive Directors To Total Num- } \\
\text { ber Of Board Members }\end{array}$ \\
\hline INSTO & Institutional Ownership & Percentage Of Institutional Ownership \\
\hline FMS & Firm Size & The Firm's Total Assets \\
\hline SLS & $\begin{array}{l}\text { Share Of The Largest Share- } \\
\text { holder }\end{array}$ & Share Of The Largest Shareholder \\
\hline
\end{tabular}

\section{Results}

First of all, we give descriptive statistic values and correlation values.

Table 2: Summary Descriptive Statistics of Variables

\begin{tabular}{|c|c|c|c|c|c|}
\hline & ARL & PNED & INSTO & FMS & SLS \\
\hline Mean & 1.707111 & .3508667 & .3932667 & 4.313602 & \\
\hline Maximum & 2.079181 & .71 & 1 & 7.093247 & .89 \\
\hline Minimum & 1.47 & 0 & 0 & 1.38 & .1287 \\
\hline Std. Dev. & .1316001 & .1190112 & .2000453 & .8434394 & \\
\hline Skewness & 0.9006 & 0.0576 & 0.4259 & 0.4523 & 0.2120 \\
\hline Kurtosis & 0.9531 & 0.0745 & 0.0009 & 0.0074 & 0.4336 \\
\hline
\end{tabular}


The table shows descriptive statistics for the dataset. It is possible to say that the data are normally distributed regarding skewness and Kurtosis.

As secondly, given correlation is presented in table below:

Table 3: Correlation Table

\begin{tabular}{|c|c|c|c|c|c|}
\hline & ARL & PNED & INSTO & FMS & SLS \\
\hline ARL & 1.0000 & & & & \\
\hline PNED & 0.0868 & 1.0000 & & & \\
\hline INSTO & 0.0948 & 0.2794 & 1.0000 & & \\
\hline FMS & -0.5722 & 0.1180 & -0.2217 & 1.0000 & \\
\hline SLS & -0.1088 & -0.0893 & -0.5171 & 0.2027 & 1.000 \\
\hline
\end{tabular}

General relationships between variables can be observed from the correlation matrix. Neither strong positive correlation nor negative correlation is observed between variables. This result is important for analysis.

Before analyzing, cross-sectional dependence of variables was tested. Results of cross-sectional dependence are given in table 4:

Table 4: Cross-Sectional Dependence

\begin{tabular}{|c|c|}
\hline Pesaran's test of cross sectional independence & 0.941 \\
\hline P-value & 0.3466 \\
\hline
\end{tabular}

$\mathrm{P}$-value greater than 0.05 indicates that there is no cross-sectional dependence. This means that the variables are not affected at the same level.

Table 5: Autocorrelation Values

\begin{tabular}{|c|c|}
\hline $\mathrm{F}(1,29)$ & 0.750 \\
\hline P-value & 0.3936 \\
\hline
\end{tabular}

P-value of over 0.05 indicates that there is no autocorrelation problem. In other words, the value of the series in any period, the previous or next period shows that the value does not move together.

Blundell and Bond (1998) and Blundell and Bond (2000) in case of N > T, the system predicted that GMM has a higher predictive power. Therefore the system proposed by the dynamic model Arellano and Bover (1995) was estimated by the GMM method using a two-stage estimation method. In this model, the two-stage prediction is preferred because the two-step estimation is considered more effective asymptotically, considering that error terms may have varying variances. Both models take place below: 
Table 6: Regression Results

\begin{tabular}{|c|c|c|c|c|c|}
\hline \multirow{18}{*}{ 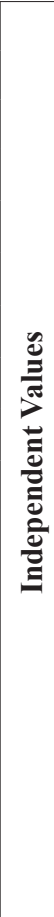 } & \multirow[t]{3}{*}{ Dependent Value } & \multirow{2}{*}{\multicolumn{2}{|c|}{$\begin{array}{c}\text { ARL } \\
\text { GMM }\end{array}$}} & \multicolumn{2}{|c|}{ ARL } \\
\hline & & & & \multicolumn{2}{|c|}{ SYSTEM GMM } \\
\hline & & t-stat & prob & T-stat & prob \\
\hline & $\operatorname{ARL}(\mathrm{t}-1)$ & -.02995 & 0.137 & .5423568 & $0.000^{*}$ \\
\hline & PNED & $(0.1091)$ & 0.382 & $(0.0779)$ & 0.790 \\
\hline & INSTO & 0.1128 & 0.125 & $(0.2658)$ & 0.24 \\
\hline & FMS & 0.0415 & 0.140 & 0.0269 & 0.75 \\
\hline & SLS & $(0.1235)$ & 0.163 & $(0.0894)$ & 0.48 \\
\hline & Cons & 4.9396 & 0.000 & 1.8446 & 0.04 \\
\hline & Effects Specification & & & & \\
\hline & Number of Groups & & & 3 & \\
\hline & Number of Instruments & & & 1 & \\
\hline & Wald chi(10) & & & 12 & \\
\hline & ProbChi2 & & & 0.02 & \\
\hline & Sargan Test & & & 30. & \\
\hline & P Value & & & 0.0 & \\
\hline & $\operatorname{AR}(1)$ & & & 0.0 & \\
\hline & $\operatorname{AR}(2)$ & & & 0.1 & \\
\hline
\end{tabular}

All models are estimated by GMM system and are significant in all cases AR (1): test of null of zero first-order serial correlation, distributed $\mathrm{N}(0,1)$ under null. AR (2) test of null of zero second-order serial correlation, distributed $\mathrm{N}(0,1)$ under null. Wald chi (10) statistics: test is a way of testing the significance of particular explanatory variables in a statistical model. Sargan test is for validity of over-identifying restrictions, distributed as indicated under null. This test of over-identifying restrictions is asymptotically distributed as under the null of instrument validity.

*Denote significance at $1 \%$ respectively.

When the variables are analyzed with GMM, the output values are above 0.05 , indicating that the model is meaningless. Therefore, system GMM method was used in second stage of the study. The results of the system GMM method are significant for only ARL (-1). It means that reporting lag of the previous term affects the next term positively. Other variables were not found significant.

\section{CONCLUSION}

An audit committee is a sub-committee of a corporate governance structure. This committee plays a significant role in monitoring the financial reporting process. One of the most important task of this committee is to publish audit reporting correctly and on time. Meanwhile, timeliness of audit reports in relation to financial reporting, 
is an important qualitative attribute of accounting information and influences whether information is useful to those who read financial statements or otherwise. The timeliness of audited corporate annual financial reports is considered to be crucial and essential factor affecting the usefulness of information made available to various users.

This study investigates the relationship between audit committee characteristics and timeliness of financial reporting for the period 2012-2017 for BIST 30 in Turkey. As independent variables for corporate governance dimensions, we used 3 variables such as board independence, institutional ownership and share of the largest shareholder. We used the firm size as control variables. We used ARL as dependent variable. To test relationship between corporate governance dimensions and audit reporting lag, we used GMM method.

According to results, board independence has no significant impact on audit report lag. This may mean that the more independent the board, the more it tends to be as an impetus for problem such as arguments or feud because of the different opinions and suggestions. This situation will prolong the audit report lag. Findings support Ilaboya and Christian (2014), Apadore and Noor (2013), as well as Shukeri and Islam's (2012) studies.

Moreover there was no significant relationship between ownership concentration and audit report lag which was found in Apadore and Noor (2013). Large shareholders have greater responsibilities to monitor management and tend to influence the company than small ones.

The result of this study shows no significant relationship was found between corporate governance dimensions and audit report lag though the study has obtained the excepted sign. In which, this indicates that internal audit neither constitute reducing the burden of external auditor and nor shorten the audit report lag. It might be because the greater the internal audit investment, the larger the scope of audit tend to be. This acquires additional effort to be hired by external auditors where the situation will prolong the audit report lag.

To enhance the explanatory power of the audit lag model, future studies may consider the strength of the firm's internal controls, ownership structure and complex transactions such as special items and related party transactions. Future studies may include more variables to give a broader view of other mechanisms on audit timeliness. Also, future researchers may consider other mechanisms such as board meetings, compensation committee and proportion of board ownership to examine the whole influence on audit report timeliness. Similarly, Following Mathew et al. (2017); Fernandes et al. (2017) studies, scoring corporate governance method can be created for each firms and relationship between corporate governance score and audit reporting lag can be investigated. 


\section{REFERENCES}

1. Akbulut, H., Güran, M.C. (2015). “Gelişmekte Olan Ülkelerde Kamu Transfer Harcamaları Ve Büyüme İlişkisi: Dinamik Panel Veri Yöntemi İle Uzun Dönem Analizi” Hacettepe Üniversitesi İktisadi ve İdari Bilimler Fakültesi Dergisi, Vol. 33, No. 1, 1-18.

2. Akdogan, Y. E., Boyacioglu, M. A., (2014). "The Effect Of Corporate Governance On Firm Performance: A Case Of Turkey" International Journal of Critical Accounting, Vol. 6, No.2, 187-210.

3. Alkhatib, K., Marji, Q., (2012). "Audit reports timeliness: Empirical evidence from Jordan" Procedia - Social and Behavioral Sciences, 62 ( 2012 ) 1342 1349

4. Apadore, K., Noor, M.M., (2013). "Determinants of Audit Report Lag and Corporate Governance in Malaysia" International Journal of Business and Management, Vol. 8, No. 15; 2013

5. Ararat, M., Black B.S., Yurtoğlu, B.B., (2017). "The Effect Of Corporate Governance On Firm Value And Profitability: Time-Series Evidence From Turkey" Emerging Market Reviesw, Vol. 30, 113-132.

6. Arellano, M., Bover, O., (1995). "Another Look At The Instrumental Variable Estimation Of Error-Components Models" Journal of Econometrics, Vol. 68, No. 1, 29-51.

7. Azubike, J.U.B., Aggreh, M., (2014)." Corporate Governance and Audit Delay in Nigerian Quoted Companies" European Journal of Accounting Auditing and Finance Research, Vol.2, No.10, pp.22-33, December 2014

8. Béjaoui, R., Bouzgarrou, H., (2014). "Determinants of Tunisian Bank Profitability" The International Journal of Business and Finance Research, Vol. 8, No.4, 121-131,

9. Blundell, R., Bond, S., (1998). "Initial Conditions And Moment Restrictions In Dynamic Panel Data Models" Journal of Econometrics, Vol. 87, No.1, 115143.

10. Blundell, R., Bond, S., (2000). "GMM Estimation With Persistent Panel Data: An Application To Production Functions" Econometric Reviews, Vol. 19, No. 3, 321-340.

11. Cengiz, S., Tosunoğlu, B., (2017). "Uluslararası Fínansal Raporlama Standartlarının Fínansal Raporlama Kalitesi Üzerindeki Etkisine Yönelik Bir Araştırma" Ataturk University Journal Of Economics \& Administrative Sciences, Vol.31, No.5, 1201-1219.

12. Cengiz, S., (2015). "Determinants of Financial Reporting" International Journal of Economics and Business Administration, ICMEB17 Special Issue. 
13. Coşkun, E., Kök, D., (2011). "Effect Of Working Capital Policies On Profitability: A Dynamic Panel Analysis” Ege Academic Review, Vol.11, 75-85.

14. Fernandes, Catarina., Farinha, Jorge., Vitorino, Martins, Francisco., Mateus, Cesario., (2017). "Supervisory Boards, Financial Crisis And Bank Performance: Do Board Characteristics Matter", Journal Of Banking Regulation, Vol. 18, 4, 310-337

15. Ferrero, M.J., (2014). “Consequences Of Financial Reporting Quality On Corporate Performance: Evidence At The International Level" Estudios de Economia, Vol. 41, No.1, 49-88.

16. Ilaboya, O.J., Christian, I., (2014). "Corporate Governance and Audit Report Lag in Nigeria" International Journal of Humanities and Social Science, Vol. 4, No. 13; November 2014

17. Martinez-Ferrero, J., (2014). “Consequences Of Financial Reporting Quality On Corporate Performance. Evidence At The İnternational Level” Estudios de Economia, Vol. 41, No-1, Page 49-88

18. Mathew, Sudha., Ibrahim, Salma., Archbold, Stuart., (2017). "Corporate Governance And Firm Risk", Corporate Governance, VOL. 18 NO. 1, 2018, Pp. 52-67,

19. Mensah, Agyei, B.K., (2018). "Impact of corporate governance attributes and financial reporting lag on corporate financial performance" African Journal of Economic and Management Studies, Vol.9 Issue: 3, pp.349-366

20. Mnasri, K., Ellouze, D., (2015). “Ownership Structure, Product Market Competition and Productivity: Evidence From Tunisia” Management Decision, Vol. 53, No. 8,1771-1805.

21. Mohamad-Nor, M.N., Shafie, R., Wan-Hussin, W.N., (2010). “Corporate Governance and Audit Report Lag In Malaysia” Asian Academy of Management Journal of Accounting and Finance, Vol. 6, No. 2, 57-84, 2010

22. Naimi, M.N.M., Rohami, S., Wan-Hussin, W.N., (2010). “Corporate Governance and Audit Report Lag in Malaysia” Asian Academy of Management Journal of Accounting and Finance, Vol.6, No.2, 1-35.

23. Needless, B, E., Turell, A., Sengur, E, D., (2012). “Corporate Governance In Turkey: Issues and Practices Of High Performance Companies” Journal Of Accounting Management Information System, Vol.11, No.4, 510-531.

24. Ohaka, J., Akani, F.N., (2017). "Timeliness and Relevance of Financial Reporting in Nigerian Quoted Firms" Management and Organizational Studies, Vol. 4, No. 2; 2017 
25. Özkan, S., Karaibrahimoğlu, Y.Z., Acar, E.C., Öz, İ.O., (2013).” Factors Affecting the Presentation Date of Financial Statements: An Application on IMKB Firms" Muhasebe Bilim Dünyası Dergisi, Vol. 15, No.3, 167-185.

26. Puasa, S., Md, Salleh,. M.F, Ahmad, A., (2014). "Audit Committee and Timeliness of Financial Reporting: Malaysian Public Listed Companies" Middle-East Journal of Scientific Research, 22 (2): 162-175

27. Shukeri, S.N., Islam, M.A., (2012). "The Determinants of Audit Timeliness: Evidence From Malaysia” Journal of Applied Sciences Research, 8(7): 33143322,2012

28. Tunay, K. B., (2014). "Türkiye'de Banka Karlılığının Belirleyicileri: Ölçek Büyüklükleri, Mülkiyet ve Finansal Krizler Temelinde Yeni Bir Analiz” Bankers Journal, Vol. 91, 3-35.

29. Yadirichukwu, E., Ebimobowei, A., (2013). "Audit Committee and Timeliness Of Financial Reports: Empirical Evidence From Nigeria" Journal of Economics and Sustainable Development, Vol.4, No.20, 2013

\section{UTICAJ ATRIBUTA KORPORATIVNOG UPRAVLJANJA NA KAŠNJENJE KORPORATIVNOG IZVJEŠTAJA REVIZIJE: SLUČAJ NA PRIMJERU PREDUZEĆA U SASTAVU INDEKSA BIST-30}

\section{SAŽETAK}

Svrha ove studije je da istraži efekte ponašanja korporativnog upravljanja na zaostajanje izvještaja revizije. Kašnjenje izvještaja revizije odnosi se na investitore $i$ druge strane. Dakle, to može uticati na stvarnu vrijednost preduzeća. U tu svrhu, 30 kompanija koje posluju u İstanbul Stock Exchange (BIST) koriste se u ovoj studiji. Podaci o preduzećima preuzeti su iz nezavisnih revizorskih izvještaja. Pošto izvještaj revizije kasni, uzeta je razlika između 31. decembra i datuma kada su kompanije objavile svoj izvještaj. U ovoj studiji je korišten udio neizvršnih direktora u ukupnom broju odbora, ukupnoj aktivi, udjelu najvećeg dioničara i free float stope kao atributa korporativnog upravljanja. Nalazi ove studije bili su zasnovani na korištenoj sistemskoj dinamičkoj ploči. Kao rezultat toga, zaključeno je da ponašanje preduzeća u korporativnom upravljanju nije bilo efikasno u kašnjenju revizorskih izvještaja u firmama.

Ključne riječi: Izvještaj o reviziji, Korporativno upravljanje, Sistemski dinamički panel

Jel: $G 32, G 34, M 21$ 